\title{
Effects of oviducal cells on the survival and fertilizing ability of fowl spermatozoa
}

\author{
K. Ashizawa, H. Nishiyama and T. Nagae \\ Department of Animal Science, Kyushu University, Fukuoka, Japan
}

\begin{abstract}
Summary. Oviducal epithelial cells were cultured and the effects of the cells on the survival and fertilizing ability of fowl spermatozoa were investigated.

When spermatozoa were incubated at $41^{\circ} \mathrm{C}$ with cells from the infundibulum, shell gland or uterovaginal junction, their motility, assessed at room temperature $\left(20-23^{\circ} \mathrm{C}\right)$, was maintained for 5 to 6 days. Fertilizing ability was also retained after culture at $41^{\circ} \mathrm{C}$ for at least 4 days. During incubation at this temperature, the spermatozoa were almost immotile and rested in close proximity to the oviducal cells. At $23^{\circ} \mathrm{C}$, the same spermatozoa were highly motile.
\end{abstract}

\section{Introduction}

When fowl spermatozoa are stored in vitro at $41^{\circ} \mathrm{C}$, normal body temperature, fertilizing ability is lost within a few hours (Schindler, Weinstein, Moses \& Gabriel, 1955), but in vivo fertilizing ability is retained for up to 34 days (Nalbandov \& Card, 1943).

Van Drimmelen (1946) found small crypts (sperm-nests) in the infundibulum of the oviduct and assumed that the storage of spermatozoa here was related to the maintenance of fertility for long periods after coitus. Similar crypts or glands have been found in the region of the uterovaginal junction (Bobr, Lorenz \& Ogasawara, 1962; Fujii, 1963; Fujii \& Tamura, 1963), and the structure and function of the glands in the infundibulum and uterovaginal junction have been extensively investigated (Aitken \& Johnston, 1963; Bobr, Lorenz \& Ogasawara, 1964a; Bobr, Ogasawara \& Lorenz, 1964b; Takeda, 1965; Ogasawara, Lorenz \& Bobr, 1966; Van Krey, Ogasawara \& Lorenz, 1966; Lorenz, Reynolds \& Gilbert, 1967; Schindler, Ben-David, Hurwitz \& Kempenich, 1967; Van Krey, Ogasawara \& Pangborn, 1967; Gilbert, Reynolds \& Lorenz, 1968 a,b,c; Lorenz \& Ogasawara, 1968; Tanaka \& Koga, 1971; Burke, Ogasawara \& Fuqua, 1972; Tingari \& Lake, 1973; Fujii, 1975). The glands, also called sperm-nests, sperm-glands and sperm-host glands, are considered to be the sites of sperm storage during the period of production of fertile eggs (see Bobr et al., 1964a; Takeda, 1965). Tanaka \& Koga (1971) reported that the uterovaginal junction and infundibulum were the best places of the oviduct for the maintenance of fertilizing spermatozoa. They also demonstrated that spermatozoa could survive in vitro at $41^{\circ} \mathrm{C}$ for at least 2 days when fresh infundibular tissue containing spermatozoa was cultured. On the other hand, Munro (1938) demonstrated that fresh spermatozoa became immotile at $40.5^{\circ} \mathrm{C}$ in synthetic diluents and oviducal juices.

From these investigations, the favourable factors contributing to the long survival of spermatozoa within the oviduct are assumed, in part, to be a specific function of the oviducal sperm-host glands in which spermatozoa are immobilized. However, there have been few investigations of the mechanisms whereby spermatozoa in the glands can survive for long periods.

In the present study, oviducal epithelial cells were cultured and the effects of the cells on the survival and fertilizing ability of spermatozoa were investigated.

\section{Materials and Methods}

White Leghorn roosters and pullets (Shaver strain obtained from Ohta Poultry Breeding Farm Inc., Saga, Japan) were used throughout the study. 


\section{Culture of oviducal cells}

Pullets were killed by decapitation and the whole body was dipped into a solution of $0.1 \%$ benzalkonium chloride after removal of the feathers. The abdominal region was disinfected with tincture of iodine and then with $70 \%$ alcohol and the oviduct was removed aseptically. The tissues taken from the infundibulum (with sperm-host glands), shell gland (lacking host glands) and uterovaginal junction (with host glands) were cleaned with Hanks'solution (Hanks \& Wallace, 1949) and the epithelia were removed with scissors and chopped into small pieces. The tissues were washed with a phosphate-buffered saline (PBS) which was modified from that of Dulbecco \& Vogt (1954) by the exclusion of $\mathrm{CaCl}_{2}$ and $\mathrm{MgCl}_{2}$. The tissues were then incubated with a trypsin solution (200 haemoglobin units of freeze-dried crystalline trypsin (Mochida Pharmaceutical Co.)/ml modified PBS) for $15 \mathrm{~min}$ at $37^{\circ} \mathrm{C}$ and the cells were dispersed in the solution according to the method of Rappaport (1956). To remove the trypsin, the cells were washed twice with Hanks' solution by centrifuging the cell suspension at $170 \mathrm{~g}$ for $5 \mathrm{~min}$. After addition of $1.0 \mathrm{ml}$ of the medium to be used for the cultures to the pellet of washed cells, the concentration of the cells per unit volume of the medium was determined with a Thoma haemocytometer and then the number of cells was adjusted to $2 \cdot 0 \times 10^{6} / \mathrm{ml}$ by adding an appropriate volume of the medium. The culture medium was made up as follows: 9 parts of minimum essential medium (Eagle, 1959) containing $0.006 \mathrm{~g}$ kanamycin sulphate and $0.0006 \mathrm{~g}$ phenol red per $100 \mathrm{ml}$ were mixed with one part of fetal calf serum (Grand Island Biological Co.) and the $\mathrm{pH}$ of the mixture was adjusted to $7 \cdot 2$ with $7.0 \%$ sodium bicarbonate solution. This fluid is called MEM in this paper. Samples $(2.0 \mathrm{ml})$ of the prepared cell suspension were seeded into small Petri dishes and cultured at $41{ }^{\circ} \mathrm{C}$ in $5 \% \mathrm{CO}_{2}+95 \%$ air by the stationary monolayer method (Dulbecco, 1952 ) in a $\mathrm{CO}_{2}$ cell culture incubator (Model 1001 : Ikemoto, Japan).

After culture for 3 days, the cells had proliferated and covered the bottom of the Petri dish. There were many epithelial cells and a few fibroblasts, suggesting that the epithelial cells had been contaminated with a few submucosal cells during removal. A few erythrocytes were also found in the medium, and were removed when the medium was exchanged.

On the $3 \mathrm{rd}$ day of culture, the culture medium $(2.0 \mathrm{ml})$ was exchanged and $0.05 \mathrm{ml}$ germ-free semen collected from the ductus deferens of a rooster was added. The sperm concentration was about $2.0 \times 10^{8} / \mathrm{ml}$.

\section{Motility of spermatozoa after incubation with oviducal cells}

The spermatozoa and oviducal cells were incubated together as described above for the oviducal cells alone. Spermatozoa incubated in cell-free medium were used as controls, but in control 1 , $0.05 \mathrm{ml}$ semen was added to $2.0 \mathrm{ml} \mathrm{MEM}$, and in control 2, the same volume of semen was added to the supernatant fluid drawn off from the culture of the cells of the uterovaginal junction after 3 days.

To investigate the effects of culture cells on the survival of spermatozoa, sperm motility was assessed at room temperature $\left(20-23^{\circ} \mathrm{C}\right)$ at intervals during the 6 -day incubation period at $41^{\circ} \mathrm{C}$. The assessment of motility was carried out by observing spermatozoa from several areas (usually 4 or 5) of the Petri dish directly from above using an inverted microscope (Nikon, MSDS), and their motility was scored on the 0 to 5 system of Wheeler \& Andrews (1943). Since the fertilizing capacity of semen varies inversely with the incidence of abnormal spermatozoa (Saeki, 1960), the number of abnormal spermatozoa was determined on the 2 nd and 4th day of incubation after addition of the semen. Semen was spread on a microscopic slide in a thin film, and the spermatozoa were fixed in formalin vapour and stained with haematoxylin. A total of 500 spermatozoa was examined and the number of abnormal spermatozoa counted.

\section{Retention of fertilizing ability in the presence of oviducal cells}

Semen collected from the ductus deferens of a rooster was divided into two parts, one for the experimental group and the other for the control. Semen for the experimental group was incubated at $41^{\circ} \mathrm{C}$ as described above for 2 or 4 days with the cells prepared from the infundibulum (with spermhost glands) or shell gland (lacking host glands). The cells from the uterovaginal junction (with host 
glands) were not used in this trial since the tissue was too small to obtain the number of cells needed. Approximately $1.5 \times 10^{8}$ spermatozoa in about $0.7 \mathrm{ml}$ culture medium were inseminated, through a 23-gauge needle attached to a syringe, into the magnum or isthmus by way of an incision made on the left side of the abdomen. There was no contamination with the cultured oviducal cells since these remained stuck to the bottom of the Petri dish. In the control group, semen was incubated in MEM without the oviducal cells and was inseminated in the same way. From 2 days after insemination, any eggs laid were collected, incubated and examined on the 4th day of incubation for fertility. The duration of fertility was also determined.

\section{Determination of sperm motility at different temperatures}

Semen was collected as clean as possible from several roosters by the one-man technique of Bogdonoff \& Shaffner (1954). The pooled semen was divided into four parts and diluted with MEM, Hanks' solution, phosphate buffer (Wilcox \& Shaffner, 1958) or seminal plasma. The semen was washed twice with the appropriate solution by centrifuging the suspension at $1500 \mathrm{~g}$ for $8 \mathrm{~min}$. Washed spermatozoa were resuspended in the solution to give a concentration of $2.0 \times 10^{8} / \mathrm{ml}$. Motilities of spermatozoa were determined at $41^{\circ} \mathrm{C}$ and $23^{\circ} \mathrm{C}$ in a thermoregulated box under $5 \%$ $\mathrm{CO}_{2}+95 \%$ air and $100 \%$ air. In another experiment, in $5 \% \mathrm{CO}_{2}+95 \%$ air, the temperature was raised from $37^{\circ} \mathrm{C}$ to $41^{\circ} \mathrm{C}$ and then dropped to $37^{\circ} \mathrm{C}$, the temperature being checked with a thermistorthermometer (Shibaura denshi, MGA), and the motility of the spermatozoa was assessed at various temperatures within this range. The motility of spermatozoa incubated in $5 \% \mathrm{CO}_{2}+95 \%$ air with cells from the infundibulum, shell gland and uterovaginal junction was also examined at $41^{\circ} \mathrm{C}$ and $23^{\circ} \mathrm{C}$.

\section{Results}

Effects of incubation with oviducal cells on the motility of spermatozoa and incidence of abnormal spermatozoa

The changes of motility assessed at $20-23^{\circ} \mathrm{C}$ during incubation at $41^{\circ} \mathrm{C}$ are shown in Table 1 . All spermatozoa incubated with epithelial cells from the infundibulum, shell gland and uterovaginal junction were capable of vigorous movement up to the 4th day. Thereafter, the motility decreased progressively and in parallel with the rapid degeneration of the oviducal cells which occurred from the 4 th to 5 th day of culture. All spermatozoa had lost motility after 6 days. There were no differences in the effects of the three types of oviducal cells. However, spermatozoa incubated in MEM (control 1) and in the first medium change (control 2) lost motility rapidly.

Table 1. Motility score (at room temperature, $20-23^{\circ} \mathrm{C}$ ) of fowl spermatozoa incubated with oviducal cells at $41^{\circ} \mathrm{C}$ in $5 \% \mathrm{CO}_{2}+95 \%$ air

\begin{tabular}{|c|c|c|c|c|c|c|c|}
\hline \multirow[b]{2}{*}{ Incubation medium } & \multicolumn{7}{|c|}{ Days after addition of semen } \\
\hline & 0 & 1 & 2 & 3 & 4 & 5 & 6 \\
\hline MEM (control 1) & $5 \cdot 0$ & $4 \cdot 5$ & $0 \cdot 0$ & $0 \cdot 0$ & $0 \cdot 0$ & $0 \cdot 0$ & 0.0 \\
\hline $\begin{array}{l}\text { MEM after } 3 \text { days of culture with uterovaginal } \\
\text { junction cells (control 2) }\end{array}$ & $5 \cdot 0$ & $4 \cdot 5$ & 0.0 & 0.0 & 0.0 & 0.0 & 0.0 \\
\hline Infundibular cells & $5 \cdot 0$ & $4 \cdot 7$ & $4 \cdot 0$ & $3 \cdot 7$ & $3 \cdot 0$ & $1 \cdot 3$ & 0.0 \\
\hline Shell gland cells & $5 \cdot 0$ & $4 \cdot 5$ & $4 \cdot 0$ & $3 \cdot 2$ & $2 \cdot 5$ & $1 \cdot 0$ & 0.0 \\
\hline Uterovaginal junction cells & $5 \cdot 0$ & $4 \cdot 7$ & $4 \cdot 0$ & $3 \cdot 5$ & $3 \cdot 0$ & $1 \cdot 5$ & 0.0 \\
\hline
\end{tabular}

Each figure represents an average of 5 trials.

The numbers of abnormal spermatozoa were also less in the incubations with oviducal cells than in the controls and the differences between them were highly significant $(P<0.01)$ (Table 2$)$. 
Table 2. The mean \pm S.E.M. (of 5 trials) percentage of abnormal fowl spermatozoa after incubation in various media

\begin{tabular}{|c|c|c|}
\hline Incubation medium & $\begin{array}{l}\text { Incubation } \\
\text { for } 2 \text { days }\end{array}$ & $\begin{array}{l}\text { Incubation } \\
\text { for } 4 \text { days }\end{array}$ \\
\hline MEM (control 1) & $89 \cdot 2 \pm 0 \cdot 8^{\mathrm{a}}$ & $94 \cdot 0 \pm 0.6^{b}$ \\
\hline MEM after 3 days of culture with uterovaginal junction cells (control 2) & $86 \cdot 1 \pm 2 \cdot 7^{a}$ & $93.1 \pm 0.5^{b}$ \\
\hline Infundibular cells & $23 \cdot 0 \pm 2 \cdot 9^{\mathrm{c}}$ & $37 \cdot 3 \pm 2 \cdot 6^{d}$ \\
\hline Shell gland cells & $21 \cdot 1 \pm 1 \cdot 6^{\mathrm{c}}$ & $38 \cdot 7 \pm 5 \cdot 2^{d}$ \\
\hline Uterovaginal junction cells & $22 \cdot 8 \pm 3 \cdot 2^{\mathrm{c}}$ & $38 \cdot 6 \pm 1 \cdot 3^{d}$ \\
\hline
\end{tabular}

Within columns, values without a common superscript differ significantly $(P<0.01)$ from each other.

\section{Effects of incubation with oviducal cells on the fertilizing ability of spermatozoa}

The results are shown in Table 3. The spermatozoa incubated for 2 days at $41^{\circ} \mathrm{C}$ with cells from the infundibulum and shell gland were highly fertile, as judged by the number of fertile eggs laid during the 1 st and 2 nd week after insemination. There was little loss of fertility after incubation for 4 days, but the duration of fertility was slightly shorter. Cells of the infundibular and shell gland areas exerted similar favourable effects on the maintenance of fertilizing ability of spermatozoa. In contrast, spermatozoa incubated in MEM had low or no fertilizing ability (Table 3), and the differences in number of fertile eggs laid and duration of fertility of the spermatozoa incubated with oviducal cells and those without the cells were significant $(P<0 \cdot 05)$.

Table 3. Fertilizing ability (shown by number of fertile eggs laid by the 6 hens inseminated in each group/total no. of eggs laid) of fowl spermatozoa incubated with MEM only (control) or with oviducal cells for (a) 2 days or (b) 4 days at $41{ }^{\circ} \mathrm{C}$ in $5 \% \mathrm{CO}_{2}+95 \%$ air

\begin{tabular}{|c|c|c|c|c|c|c|c|}
\hline & & \multicolumn{2}{|c|}{ Control } & \multicolumn{2}{|c|}{ Infundibular cells } & \multicolumn{2}{|c|}{ Shell gland cells } \\
\hline & & 1st week & 2nd week & 1st week & 2nd week & 1st week & 2nd week \\
\hline \multicolumn{8}{|c|}{ (a) Trial 1} \\
\hline & Fertilized eggs & $2 / 16$ & $0 / 15$ & $29 / 32$ & $23 / 38$ & $28 / 33$ & $23 / 34$ \\
\hline & $(\%)$ & $(12 \cdot 5)$ & $(0)$ & $(90 \cdot 6)$ & $(60 \cdot 5)$ & $(84 \cdot 8)$ & $(67 \cdot 6)$ \\
\hline \multicolumn{8}{|c|}{ Trial 2} \\
\hline & Fertilized eggs & $2 / 34$ & $0 / 30$ & $20 / 23$ & $15 / 24$ & $25 / 30$ & $17 / 29$ \\
\hline & $(\%)$ & $(5 \cdot 9)$ & $(0)$ & $(87 \cdot 0)$ & $(62 \cdot 5)$ & $(83 \cdot 3)$ & $(58 \cdot 6)$ \\
\hline & Trial $1+$ Trial 2 & \multirow{2}{*}{\multicolumn{2}{|c|}{0.5}} & \multirow{2}{*}{\multicolumn{2}{|c|}{$\begin{array}{rr}88.8 \% & 61.5 \% \\
13.3 & \end{array}$}} & \multirow{2}{*}{\multicolumn{2}{|c|}{$\begin{array}{l}84.1 \% \\
14.8\end{array}$}} \\
\hline & Average duration of fertility (days) & & & & & & \\
\hline \multirow[t]{3}{*}{ (b) } & Fertilized eggs & $0 / 32$ & $0 / 31$ & $21 / 23$ & $12 / 30$ & $26 / 29$ & $13 / 29$ \\
\hline & $(\%)$ & (0) & (0) & $(91 \cdot 3)$ & $(40 \cdot 0)$ & $(89 \cdot 7)$ & $(44 \cdot 8)$ \\
\hline & Average duration of fertility (days) & \multicolumn{2}{|c|}{0} & \multicolumn{2}{|c|}{$10 \cdot 2$} & \multicolumn{2}{|c|}{$11 \cdot 7$} \\
\hline
\end{tabular}

\section{Sperm motility at $23^{\circ} \mathrm{C}$ and $41^{\circ} \mathrm{C}$}

The spermatozoa in seminal plasma and phosphate buffer were similar at the two temperatures in that they were almost all motile in the former and almost immotile in the latter. In MEM and Hanks' solution, however, motility was practically inhibited at $41^{\circ} \mathrm{C}$ although vigorous movement was seen at $23^{\circ} \mathrm{C}$. The immobilization at $41^{\circ} \mathrm{C}$ was reversible since active motility was again resumed when the temperature was lowered to $23^{\circ} \mathrm{C}$. When incubated with oviducal cells, the spermatozoa were immobilized at $41^{\circ} \mathrm{C}$, remaining on the surface of the cells, and were highly motile at $23^{\circ} \mathrm{C}$. Examination of motility as the temperature was changed from $37^{\circ} \mathrm{C}$ to $41^{\circ} \mathrm{C}$ and back to $37^{\circ} \mathrm{C}$ revealed that spermatozoa in MEM or Hanks' solution became immotile between $40 \cdot 2$ and $41 \cdot 0^{\circ} \mathrm{C}$.

\section{Discussion}

It is generally considered that the motility and metabolic activity of spermatozoa are inhibited at low temperatures, resulting in an extension of their life-span and fertilizing ability in vitro (Salisbury 
\& Lodge, 1962; Mann, 1964). Consequently, fowl spermatozoa have usually been stored at temperatures below $10^{\circ} \mathrm{C}$.

Even when fowl spermatozoa were stored at low temperature, the fertility results obtained after 24-hr storage were poor in the early experiments. As suitable diluents for fowl spermatozoa were developed, fertility was improved; 64\% (Lake, 1960) and 83-95\% (Van Wambeke, 1967) after storage for $24 \mathrm{hr}$, and $47 \%$ (Lake, 1960), 79\% (Wilcox, 1960) and 76\% (Wilcox \& Clark, 1962) with spermatozoa stored for 2 days. However, when semen was stored at $41{ }^{\circ} \mathrm{C}$, fertility results were reported to be only 7 and $3 \%$ after storage for 2 or $4 \mathrm{hr}$ respectively (Schindler et al., 1955).

The results obtained from our experiments revealed that when fowl spermatozoa were stored at $41^{\circ} \mathrm{C}$ with oviducal epithelial cells, motility (assessed at $20-23^{\circ} \mathrm{C}$ ) was retained for $5-6$ days and fertilizing ability for 4 days. The insemination site for our experiment was different from the usual one and intramagnal or intraisthmic insemination may have resulted in higher fertility than after intravaginal insemination (Tanaka \& Koga, 1971). However, Van Krey et al. (1966) reported that intramagnal insemination resulted in a lower 1st-week fertility and a longer duration of fertility than did intrauterine or intravaginal insemination.

For optimal survival of cultured cells the medium must be exchanged every 2-3 days. In the conditions of our experiments, however, renewal of the medium was impossible and rapid degeneration of the cultured cells was observed 4-5 days after addition of the semen. In association with this degeneration, the motility (at $20-23^{\circ} \mathrm{C}$ ) of the spermatozoa declined rapidly, suggesting that living oviducal cells may exert a favourable effect on the survival of spermatozoa and that, if the cultured oviducal cells were able to survive for a longer period, the life of the spermatozoa would also be prolonged.

The sperm-host glands are considered to be the storage sites for those spermatozoa that are responsible for continued fertilization of eggs after one insemination, since large numbers of normal spermatozoa are found there, in decreasing number, for as long as fertilized eggs are produced (Fujii \& Tamura, 1963; Bobr et al., 1964a). These glands are assumed to supply nutrients to the spermatozoa and to remove the waste products of sperm metabolism (Van Tienhoven, 1961), thereby exerting a specific favourable effect on the spermatozoa stored in the glands, though there is no direct evidence to support this assumption.

The results of the present work, in which the epithelial cells of the oviduct were dispersed and cultured, showed that there was no difference in the maintenance of motility and fertilizing ability of spermatozoa incubated with cells from the infundibulum (with sperm-host glands) and those from the shell gland (lacking host glands). Thus it appears that the cells of the infundibulum may not exert a specific influence, and that an environment provided by living cells is all that is necessary for the survival of spermatozoa for a prolonged period in the fowl oviduct.

The relationship between the motility of fresh spermatozoa and temperature was investigated by Munro (1938). He reported that most types of synthetic diluents and oviducal juices supported motility at room temperature but inhibited it at body temperature, while several natural fluids such as seminal plasma, blood serum and shell gland fluid supported motility at all temperatures examined. Schindler \& Nevo (1962), however, reported that spermatozoa in Ringer's solution showed high motility at $40^{\circ} \mathrm{C}$. The results of our experiments were similar to those of Munro (1938), whether or not oviducal cells were present.

These results, together with the evidence that the spermatozoa stored in sperm-host glands are in contact with microvilli of the epithelium (Van Krey et al., 1967; Tingari \& Lake, 1973), suggest that fowl spermatozoa are quiescent while they are stored in the sperm-host glands in close proximity to the epithelial cells, and that these are the conditions that favour the prolonged survival of spermatozoa within the oviduct.

We are greatly indebted to Dr T. Yanase, Professor of Internal Medicine I, Kyushu University and to Dr R. Takagi, Professor of School of Health Sciences, Kyushu University, for their continued valuable advice on cell culture technique. We also thank Mr F. Okamura for skilled technical assistance. 


\section{References}

AItKen, R.N.C. \& Johnston, H.S. (1963) Observations on the fine structure of the infundibulum of the avian oviduct. J. Anat. 97, 87-99.

BOBR, L.W., Lorenz, F.W. \& OGaSawara, F.X. (1962) The role of uterovaginal junction in storage of cock spermatozoa. Poult. Sci. 41, 1628, Abstr.

Bobr, L.W., Lorenz, F.W. \& Ogasawara, F.X. (1964a) Distribution of spermatozoa in the oviduct and fertility in domestic birds. I. Residence sites of spermatozoa in fowl oviducts. J. Reprod. Fert. 8 , 39-47.

Bobr, L.W., Ogasawara, F.X. \& Lorenz, F.W. (1964b) Distribution of spermatozoa in the oviduct and fertility in domestic birds. II. Transport of spermatozoa in the fowl oviduct. J. Reprod. Fert. 8 , 49-58.

Bogdonoff, P.D., JR \& Shaffner, C.S. (1954) The effect of $\mathrm{pH}$ on in vitro survival, metabolic activity, and fertilizing capacity of chicken semen. Poult. Sci. 33, 665-669.

Burke, W.H., Ogasawara, F.X. \& Fuqua, C.L. (1972) A study of the ultrastructure of the uterovaginal sperm-storage glands of the hen, Gallus domesticus, in relation to a mechanism for the release of spermatozoa. J. Reprod. Fert. 29, 29-36.

Dulbecco, R. (1952) Production of plaques in monolayer tissue cultures by single particles of an animal virus. Proc. natn. Acad. Sci. U.S.A. 38, 747-752.

Dulbecco, R. \& VogT, M. (1954) Plaque formation and isolation of pure lines with poliomyelitis viruses. J. exp. Med. 99, 167-182.

EAGLE, H. (1959) Amino acid metabolism in mammalian cell cultures. Science, $N . Y .130,432-437$.

Full, S. (1963) Histological and histochemical studies on the oviduct of the domestic fowl with special reference to the region of uterovaginal juncture. Archum histol. jap. 23, 447-459.

Funi, S. (1975) Scanning electron microscopical observation on the mucosal epithelium of hens' oviduct with special reference to the transport mechanism of spermatozoa through the oviduct. J. Fac. Fish. Anim. Husb., Hiroshima Univ. 14, 1-13.

Fujir, S. \& TAMURA, T. (1963) Location of sperms in the oviduct of the domestic fowl with special reference to storage of sperms in the vaginal gland. J. Fac. Fish. Anim. Husb., Hiroshima Univ. 5, 145-163.

Gilbert, A.B., Reynolds, M.E. \& Lorenz, F.W. (1968a) Distribution of spermatozoa in the oviduct and fertility in domestic birds. V. Histochemistry of the uterovaginal sperm-host glands of the domestic hen. J. Reprod. Fert. 16, 433-444.

Gilbert, A.B., ReYnolds, M.E. \& LoRenz, F.W. (1968b) Distribution of spermatozoa in the oviduct and fertility in domestic birds. VII. Innervation and vascular supply of the uterovaginal sperm-host glands of the domestic hen. J. Reprod. Fert. 17, 305-310.

Gilbert, A.B., ReYnolds, M.E. \& Lorenz, F.W. (1968c) Distribution of spermatozoa in the oviduct and fertility in domestic birds. VIII. The effect of a foreign object in the uterus on secretions of the sperm-host glands and the survival of spermatozoa in the oviduct of the domestic hen. $J$. Reprod. Fert. 17, 311-314.

Hanks, J.H. \& Wallace, R.E. (1949) Relation of oxygen and temperature in the preservation of tissues by refrigeration. Proc. Soc. exp. Biol. Med. 71, 196-200.

LAKe, P.E. (1960) Studies on the dilution and storage of fowl semen. J. Reprod. Fert. 1, 30-35.

Lorenz, F.W. \& Ogasawara, F.X. (1968) Distribution of spermatozoa in the oviduct and fertility in domestic birds. VI. The relations of fertility and embryo normality with site of experimental insemination. $J$. Reprod. Fert. 16, 445-455.

LOREnZ, F.W., ReYNolds, M.E. \& GilberT, A.B. (1967) Secretory activity of the sperm-host glands of the domestic fowl. Physiologist, Wash. 10, 236.

MANN, T. (1964) Influence of ion concentration, dilution, temperature, and other extraneous factors, on semen in vitro. In The Biochemistry of Semen and of the Male Reproductive Tract, p. 356. Methuen, London.

MUNRo, S.S. (1938) Fowl sperm immobilization by a temperature-media interaction and its biological significance. Q. Jl exp. Physiol. 27, 281-291.

Nalbandov, A. \& Card, L.E. (1943) Effect of stale sperm on fertility and hatchability of chicken eggs. Poult. Sci. 22, 218-226.

Ogasawara, F.X., Lorenz, F.W. \& Bobr, L.W. (1966) Distribution of spermatozoa in the oviduct and fertility in domestic birds. III. Intra-uterine insemination of semen from low-fecundity cocks. $J$. Reprod. Fert. 11, 33-41.

RAPPAPORT, C. (1956) Trypsinization of monkeykidney tissue: an automatic method for the preparation of cell suspensions. Bull. Wld Hith Org. 14, 147-166.

SAEKI, Y. (1960) Crooked-necked spermatozoa in relation to low fertility in the artificial insemination of fowl. Poult. Sci. 39, 1354-1361.

SAlisbury, G.W. \& LoDge, J.R. (1962) Metabolism of spermatozoa. Adv. Enzymol. 24, 35-104.

Schindler, H. \& Nevo, A. (1962) Reversible inactivation and agglutination of fowl and bull spermatozoa under anaerobic conditions. J. Reprod. Fert. 4, 251-265.

Schinder, H., Weinstein, S., Moses, E. \& Gabriel, I. (1955) The effect of various diluents and storage times on the fertilizing capacity of cock semen. Poult. Sci. 34, 1113-1117.

Schindler, H., Ben-David, E., Hurwitz, S. \& KemPENICH, O. (1967) The relation of spermatozoa to the glandular tissue in the storage sites of the hen oviduct. Poult. Sci. 46, 1462-1471.

TAKEDA, A. (1965) Behavior of spermatozoa in the genital tract of the hen. II. Survival of spermatozoa in the ligated oviduct. Jap. Poult. Sci. 2, 115-122.

Tanaka, K. \& Koga, O. (1971) Studies on the maintenance of fertilizing spermatozoa in the hen's oviduct. Jap. J. zootech. Sci. 42, 237-249.

Tingari, M.D. \& LAKE, P.E. (1973) Ultrastructural studies on the uterovaginal sperm-host glands of the domestic hen, Gallus domesticus. J. Reprod. Fert. 34, $423-431$. 
VAN DRIMMEleN, G.C. (1946) "Spermnests" in the oviduct of the domestic hen. Anim. Breed. Abstr. 15, 283-284.

Van Krey, H.P., Ogasawara, F.X. \& Lorenz, F.W. (1966) Distribution of spermatozoa in the oviduct and fertility in domestic birds. IV. Fertility of spermatozoa from infundibular and uterovaginal glands. J. Reprod. Fert. 11, 257-262.

Van Krey, H.P., Ogasawara, F.X. \& Pangborn, J. (1967) Light and electron microscopic studies of possible sperm gland emptying mechanisms. Poult. Sci. 46, 69-78.

Van Tienhoven, A. (1961) Endocrinology of Reproduction in Birds. In Sex and Internal Secretions, Vol. II, pp. 1088-1169. Ed. W. C. Young. Williams \& Wilkins, Baltimore.

VAN WAMBEKE, F. (1967) The storage of fowl sperma- tozoa. I. Preliminary results with new diluents. J. Reprod. Fert. 13, 571-575.

WheEler, N.C. \& ANDrews, F.N. (1943) The influence of season on semen production in the domestic fowl. Poult. Sci. 22, 361-367.

WILCox, F.H. (1960) Effect on fertility of temperature, handling methods, Lake's solution and the addition of egg white, egg yolk, and sugars to the diluent used in storing chicken semen. Poult. Sci. 39, 459467.

Wilcox, F.H. \& Clark, R.G. (1962) Semen dilution during storage and washing. Poult. Sci. 41, 10911096.

Wilcox, F.H. \& ShaffNer, C.S. (1958) The effect of different handling methods and added fructose on the fertilizing ability of chicken spermatozoa after storage. Poult. Sci. 37, 1353-1357.

Received 31 December 1975 